\title{
Quality of Teachers' Performance Evaluation in Public and Private Secondary Schools of Karachi, Pakistan
}

\author{
Ryu Ju Hyun ${ }^{*}$ \\ Shahida Sajjad**
}

\begin{abstract}
This descriptive study explored the quality of teachers' performance evaluation process used in schools of Karachi city. The sample of this study included 50 principals and 250 teachers from public and private schools. Using structured, closed-ended questionnaire, data were analyzed by descriptive statistics and Independent $t$ test. The results of the study indicate that both private and public secondary schools in Karachi have a proper system of teachers' performance evaluation but a significant difference exists in terms of quality. Unlike private schools, the performance of teachers in public schools is not monitored regularly, the results of performance evaluation do not accurately reflect a teacher's ability, and the rating system used to evaluate teachers is not useful for the growth of teachers and principals. The results concluded that both public and private secondary schools in Karachi have a trustworthy system of teachers' performance evaluation. The study also revealed that the quality of teachers' performance evaluation in private secondary schools is better than public secondary schools in Karachi. The private schools have a formative system of teachers' performance evaluation that is reflected through regular informal visits by their principal to check the performance of teachers. In contrast the public schools have a summative evaluation system to check the performance of teachers which was reflected through lack of regular visits by principal to check the performance of teachers.
\end{abstract}

Keywords: teachers' performance evaluation, quality, public and private secondary schools

\footnotetext{
*Ph.D Scholar, Greenwich University, Pakistan. Email: kjsiran@gmail.com

** Dean Faculty of Social Sciences, Malir University of Science \& Technology, Karachi Email: shahida_sajjad75270@yahoo.com
} 


\section{Introduction}

The success of any nation is highly based on its education system. Therefore, quality is now considered as a fundamental criteria of education system and teachers play an instrumental role in achieving the quality education. Teachers are the pillars of any education system as they have an important responsibility to prepare the students as a future responsible citizen of a country. The research show that students' learning is affected by teachers' performance. Therefore, the purpose of teachers' performance evaluation as important for their growth has always been considered by the old and new researchers (Cubberly,1929; Danielson, 2001; Zimmerman \& Deckert-Pelton, 2003).

Pakistan aims to compete in the global knowledge economy through a quality education system from pre-primary to higher education level and this process rely mainly on teachers. The Government of Pakistan is responsible for providing quality education at all levels of education therefore the Ministry of Education in 2009 has been adopted and implemented National Professional Standards of Teachers to improve the quality of education (Government of Pakistan, 2009). These standards state the skills, knowledge, and abilities needed by teachers to enhance students' learning. All these steps taken to improve the quality of education will not be effective without having a proper system of teachers' performance evaluation.

Researchers always emphasized about importance of a system for teachers' evaluation (Danielson \& McGreal, 2000). But the question is that do our schools really have a system of teacher performance evaluation or not and if the schools have any system, what is the outcome of teachers' performance evaluation. The private-sector schools have some system of teachers' performance evaluation to monitor the standard of their education but the public-sector schools are just doing this task as merely to fulfill the requirement and not really understanding its purpose. Danielson (2001) stated that the process of teachers' performance evaluation is worthless activity as such evaluation is not taken seriously by teachers and evaluators.

In Pakistan, there are two broad categories of schools which are providing education namely the schools belonging to public sector and the schools belonging to private sector. The public schools educate students through Urdu medium of instruction, do not charge any fee till secondary level of education and mostly middle-class families send their children to these schools (Rahman, 2002). The private schools educate students through English medium and mostly upper-class families send 
their children to these schools (Abbas, 2003). Therefore, this study was planned to explore the quality of teachers' performance evaluation in public and private secondary schools in Karachi as perceived by their teachers and principals.

The study is expected to create awareness among principals and teachers about the importance of a sound performance evaluation system for teachers to improve their performance and achieve better results of their students by enhancing teaching/learning process in class room thereby improving the quality of education.

\section{Literature Review}

Performance evaluation is defined variously by the researchers. Erdogen (2002) viewed performance evaluation as the process of assessing and perceiving an employee's performance. Payos and Zorilla (2003) stated that it is a method of evaluating and providing feedback on where and how the employees meet work expectations over a given period. Aguinis (2009) explained that performance evaluation is a system which measures the difference in previous and present performance. Stronge (2010) acknowledged that collaboration, cooperation, communication and commitment are important aspects of performance evaluation to produce quality teachers. Wilson (2005) preserved that performance evaluation includes inspiration, information, skills, activities and improvement of teaching areas.

Performance evaluation is an integral part of assessing human resource utilization and productivity in any organization. School is an organization performing the function of preparing citizens of a country. The foundation of preparing future citizens depends on education system of school and teachers are instrumental in whole process of education and development of children as responsible citizens of society in future. Therefore, it is inevitable to have a comprehensive system of teachers' performance evaluation. Many studies were conducted on performance evaluation system and its importance at different level of education and in different sectors.

The role of school principal being an educational leader is important in the process of performance evaluation of their teachers and it is required that the teachers and principals should know the importance of performance evaluation of teachers because this can enhance not only the performance of teachers but also improve learning of their students. Robbins and Alvy (2003) emphasized on collaboration among teachers 
for their students' assessment. The teachers should know the parameters on which their performance is evaluated.

Researchers argue that performance appraisal is beneficial for the individual as well as for the organization (Vanci-Osam \&Askit, 2000; Lam, 2001) because all educational improvement are based on results achieved from teachers' performance appraisal (Stronge \& Tucker, 2003) but many studiesshow that this evaluation is merely a formality although it should be meant to improve the growth of the teachers (Stronge\& Tucker, 1999)

Cokins (2004) and Roberts (2003) emphasized on trust of employees on performance evaluation system and transparency in the process of evaluation involving employees in the process of evaluation. Mani (2002) argued satisfaction of employees with the evaluators and trust on performance appraisal system whereas Sarwar and Awan (2013) in a study explored that the teachers don't know basis their performance evaluation, because it is not discussed with them rather it is kept confidential.

In Pakistan, teachers' performance evaluation system exists in both private and public secondary schools with different approaches. In public schools this evaluation is kept confidential and therefore termed as "Annual Confidential Report" (ACR). Currently it is called "Performance Evaluation Report" (PER) based on teachers' overall characters and attitude without considering the role of teacher in classroom teaching and effective learningof their students. In Pakistan, the performance evaluation in public schools is carried out annually for the accountability of teachers and to provide annul increments so it has no concern with the quality of education or for the professional development of teachers. In contrast, most of the private schools in Pakistan have performance evaluation based on classroom performance of a teacher and successful learning of students (Rahman, 2006).

\section{Research Methodology}

This descriptive study was designed by using a survey model. Statistical Package for Social Sciences (SPSS) Version 21 was used for data analysis. Hypotheses were tested by using descriptive statistics and "Independent-Sample t-tests" with significance noted at $\mathrm{p}<0.05$.

\section{Population and Sample}

This study was designed to find out the quality of teachers' performance evaluation in public and private secondary schools of 
Karachi therefore the population of study included all teachers and principals of all public schools administered by Federal and Provincial Government of Sindh and private secondary schools located in Karachi city. The principals were selected as they are responsible to evaluate their teachers' performance and the teachers were selected as they are the appraises. Therefore, it was important to find out the opinion of both groups about the quality of teachers' performance evaluation.

The sample of this study included two groups of respondents: teachers and principals of secondary level schools (grades 6-10) selected through convenience sampling method which is a process of including whoever happen to be available or volunteer(Gay, 2013). The sample size was comprised of 25 public schools (run by Federal Government and Provincial Government) and 25 private schools. These schools were selected through purpose sampling. The categories of the schools are shown in table 1 . The first group comprised 50 principals, 25 from public schools and 25 from private schools located in Karachi city. The second group comprised 250 teachers, 125 from public schools and 125 from private schools. The teachers and principals were selected from same schools.

Table 1

Categories of Schools

\begin{tabular}{lllllll}
\hline Administrative Control by & Schools & \multicolumn{2}{c}{ Principles } & \multicolumn{2}{l}{ Teachers } \\
\hline & $\mathrm{N}$ & $\%$ & $\mathrm{~N}$ & $\%$ & $\mathrm{~N}$ & $\%$ \\
\hline Federal Government & 5 & 10.00 & 5 & 10.00 & 25 & 10.00 \\
Provincial Government & 20 & 40.00 & 20 & 40.00 & 100 & 40.00 \\
Private & 25 & 50.00 & 25 & 50.00 & 125 & 50.00 \\
Total & 50 & 100 & 50 & 100 & 250 & 100 \\
\hline
\end{tabular}

\section{Demographic Characteristics of Sample}

The demographic characteristics of the principals are reflected through table 2 . Out of 50 principals from secondary schools, 13 were male and 37 were female. Majority of the principals were 30 to 39 years old and majority of them were post graduate. All principals from public sector schools were having a professional qualification as either B.Ed. $(52 \%)$ or M.Ed. (48\%) but some of the principals from private schools were not having any professional qualifications (16\%). The working experience of majority of the principals was more than 11years. 
Table 2

Demographic Characteristics of Principals $(N=50)$

\begin{tabular}{|c|c|c|c|c|c|c|}
\hline & & \multicolumn{2}{|c|}{ Public Schools } & \multicolumn{2}{|c|}{ Private Schools } & \multirow{2}{*}{$\begin{array}{l}\text { Total } \\
\text { N (\%) }\end{array}$} \\
\hline & & $\mathrm{n}$ & $\%$ & $\mathrm{n}$ & $\%$ & \\
\hline \multirow[t]{2}{*}{ Gender } & Male & 07 & 28.0 & 06 & 24.0 & $13(26 \%)$ \\
\hline & Female & 18 & 72.0 & 19 & 76.0 & $37(74 \%)$ \\
\hline \multirow[t]{4}{*}{ Age in years } & $<30$ & 02 & 08.0 & 03 & 12.0 & $05(10 \%)$ \\
\hline & $30-39$ & 10 & 40.0 & 11 & 44.0 & $21(42 \%)$ \\
\hline & $40-49$ & 06 & 24.0 & 02 & 08.0 & $08(16 \%)$ \\
\hline & $50+$ & 07 & 28.0 & 09 & 36.0 & $16(32 \%)$ \\
\hline Academic & Graduate & 04 & 16.0 & 03 & 12.0 & $07(14 \%)$ \\
\hline \multirow[t]{2}{*}{ Qualification } & Master & 21 & 84.0 & 21 & 84.0 & $42(84 \%)$ \\
\hline & Ph.D. & 00 & 00 & 01 & 04.0 & $01(02 \%)$ \\
\hline Professional & B.Ed. & 13 & 52.0 & 08 & 32.0 & $21(42 \%)$ \\
\hline Qualification & M.Ed. & 12 & 48.0 & 09 & 36.0 & $21(42 \%)$ \\
\hline Experience & $1-3$ & 04 & 16.0 & 03 & 12.0 & $07(14 \%)$ \\
\hline \multirow[t]{3}{*}{ in years } & $4-7$ & 05 & 20.0 & 05 & 20.0 & $10(20 \%)$ \\
\hline & $8-11$ & 06 & 24.0 & 05 & 20.0 & $11(22 \%)$ \\
\hline & $11+$ & 10 & 40.0 & 12 & 48.0 & $22(44 \%)$ \\
\hline
\end{tabular}

Table 3 describes the demographic characteristics of 250 secondary school teachers comprising of 54 male and 196females. Majority of the teachers $(42 \%)$ were 30 to 39 years old and majority of them were postgraduate $(84 \%)$. All teachers from public sector schools were having a professional qualification as either B.Ed. (52\%) or M.Ed. (48\%) but only less than fifty percent of the teachers from private schools were having professional qualifications as B.Ed. (42\%) or M.Ed. (42\%). The working experience of majority of the teachers was between 8 -11years $(31.2 \%)$. 
Table 3

Demographic Characteristics of Teachers $(N=250)$

\begin{tabular}{lllllll}
\hline & & \multicolumn{2}{l}{ Public Schools } & \multicolumn{2}{l}{ Private Schools } & Total \\
\hline Gender & & $\mathrm{n}$ & $\%$ & $\mathrm{n}$ & $\%$ & $\mathrm{~N}(\%)$ \\
& Male & 28 & 22.40 & 26 & 20.80 & $54(21.6 \%)$ \\
Age in years & Female & 97 & 77.60 & -99 & 79.20 & $196(78.4 \%)$ \\
& $<30$ & 25 & 20.00 & 45 & 36.00 & $70(28.0 \%)$ \\
& $30-39$ & 30 & 24.00 & 64 & 51.20 & $94(37.6 \%)$ \\
Academic & $40-49$ & 38 & 30.40 & 06 & 04.80 & $44(17.6 \%)$ \\
Qualification & $50+$ & 32 & 25.60 & 10 & 08.00 & $42(16.8 \%)$ \\
& Graduate & 89 & 71.20 & 72 & 57.6 & $161(64.4 \%)$ \\
& Master & 32 & 25.60 & 42 & 33.6 & $85(34.0 \%)$ \\
Professional & M.Phil. & 03 & 02.40 & 04 & 03.2 & $07(02.8 \%)$ \\
Qualification & Ph.D. & 01 & 00.80 & 07 & 05.6 & $08(03.2 \%)$ \\
& & & & & & \\
Experience & PTC & 00 & 00.00 & 03 & 02.40 & $03(1.2 \%)$ \\
in years & B.Ed. & 62 & 49.60 & 51 & 40.80 & $113(45.2)$ \\
& M.Ed. & 63 & 50.40 & 34 & 27.20 & $97(38.8 \%)$ \\
& $1-3$ & 10 & 08.00 & 39 & 31.20 & $49(19.6 \%)$ \\
& $4-7$ & 33 & 26.40 & 33 & 26.40 & $66(26.4 \%)$ \\
& $8-11$ & 51 & 40.80 & 27 & 21.60 & $78(31.2 \%)$ \\
& $11+$ & 31 & 24.80 & 26 & 20.80 & $57(22.8 \%)$ \\
\hline
\end{tabular}

\section{Instrument of the Study}

The study was carried out with the help of two structured questionnaires comprising of the same closed- ended items, one for the principals and one for the teachers. Section I of each questionnaire included demographic details of participants whereas section II was designed having eight items as shown in table number $4-11$ to check the quality of the process of teacher's performance evaluation. Responses were rated for each of the statements using a five- point Likert scale from one to five: 1 - strongly disagree, 2 - disagree, 3 - Neither agree nor disagree, 4 - agree, and 5 - strongly agree. For the content validity, the questionnaires were designed after reviewing the related literature based on National Professional Standards for Teachers in Pakistan (Government of Pakistan, 2009), and research studies conducted in this area (Khan, Chandio, \& Farooqi, 2014; Musil, 2014; Shakir, \& Adeeb, 2014). The questionnaire was also reviewed by the experts in the field of education for their guidance. For face validity, the questionnaires were further pre-tested through 10 principals and 10 teachers who were later not included in the sample. The Reliability Coefficient (Cronbach alpha) was calculated as 0.694 . 


\section{Results}

Research Question: How do principals and teachers of public and private secondary schools in Karachi determine the quality of teachers' performance evaluation process in their schools?

The quality of teachers' performance evaluation in schools was measured through eight parameters as reflected through hypotheses given in table 4-8.

Hypothesis 1: There is a significant difference among the public and private secondary schools in Karachi having a proper system of teachers' performance evaluation in their schools.

Table 4

Schools having Proper System of Teachers' Performance Evaluation $(N=300)$

\begin{tabular}{llllll}
\hline Responses & Schools & Mean & $\begin{array}{l}\text { Standard } \\
\text { Deviation }\end{array}$ & t-value & $p$ \\
\hline $\begin{array}{l}\text { School have proper system of } \\
\text { teachers' performance } \\
\text { evaluation. }\end{array}$ & Public & 4.07 & .667 & .084 & .933 \\
& Private & 4.07 & .711 & & \\
\hline
\end{tabular}

Significant $\alpha=0.05$

In table 4 , the value of " $t$ " $(0.084)$ is not significant as the " $p$ " value $(0.933)>0.05$ therefore it is concluded that there was no significant difference among public schools and private schools about having a proper system of teachers' performance evaluation in their schools.

Hypothesis 2: There is a significant difference among the public and private secondary schools in Karachi regrading constant monitoring of teacher's performance in their schools.

Table 5

Teachers' Performance is Constantly Monitored in Schools $(N=300)$

\begin{tabular}{lllllll}
\hline Responses & Schools & Mean & $\begin{array}{l}\text { Standard } \\
\text { Deviation }\end{array}$ & t-value & $p$ \\
\hline $\begin{array}{l}\text { Teacher's performance } \\
\text { constantly monitored. }\end{array}$ & is & Public & 2.23 & .958 & -20.605 & .000 \\
& Private & 4.19 & .662 & & \\
\hline
\end{tabular}

Significant $\alpha=0.05$

In table 5 the value of " $t$ " $(-20.605)$ is significant as the " $p$ " value $(0.000)<0.05$ therefore it is concluded that there was a significant 
difference among public schools and private schools about the response that teachers' performance evaluation in schools is constantly monitored in their schools.

Hypothesis 3: There is a significant difference among the public and private secondary schools in Karachi considering that results of performance evaluation accurately reflect a teacher's ability.

Table 6

Results of Performance Evaluation Accurately Reflect a Teacher's Ability $(N=300)$

\begin{tabular}{lllllll}
\hline Responses & Schools & Mean & $\begin{array}{l}\text { Standard } \\
\text { Deviation }\end{array}$ & t-value & $p$ \\
\hline $\begin{array}{l}\text { Results of performance } \\
\text { evaluation accurately reflect a } \\
\text { teacher's ability. }\end{array}$ & Public & 2.71 & 1.121 & -11.863 & .000 \\
& & & & & \\
\hline
\end{tabular}

Significant $\alpha=0.05$

Table 6 shows that the value of " $t$ " $(-11.176)$ is significant as the " $p$ " value $(0.000)<0.05$ therefore it is concluded that there was a significant difference among public schools and private schools about the response that the rating system used to evaluate teachers is useful for the growth of principals and teachers.

Hypothesis 4: There is a significant difference among the public and private secondary schools in Karachi having adequate number of classroom observations of teacher by the principal to evaluate instructional skills of teacher.

Table7

Adequate Number of Classroom Observations of Teacher by the Principal to Evaluate Instructional Skills of Teacher $(N=300)$

\begin{tabular}{llllll}
\hline Response & Schools & Mean & $\begin{array}{l}\text { Standard } \\
\text { Deviation }\end{array}$ & t-value & $p$ \\
\hline $\begin{array}{l}\text { Adequate number of classroom } \\
\text { observations of teacher by the } \\
\text { principal to evaluate instructional } \\
\text { skills of teacher. }\end{array}$ & Public & 2.39 & .843 & -17.671 & .000 \\
& Private & & & & \\
\hline
\end{tabular}

Significant $\alpha=0.05$ 
Table 7 shows that the value of "t" $(-17.671)$ is significant as the "p" value $(0.000)<0.05$ therefore it is concluded that there was a significant difference among public schools and private schools about the response of having adequate number of classroom observations by principal to evaluate instructional skills of teachers.

Hypothesis 5: There is a significant difference among the public and private secondary schools in Karachi considering usefulness of the rating system used to evaluate teachers is useful for the growth of principals and teachers.

Table 8

Usefulness of Rating System used to Evaluate Teachers for the Growth of Teachers and Principal $(N=300)$

\begin{tabular}{llllll}
\hline Response & Schools & Mean & $\begin{array}{l}\text { Standard } \\
\text { Deviation }\end{array}$ & t-value & $p$ \\
\hline $\begin{array}{l}\text { Usefulness of rating system used } \\
\text { to evaluate teachers for the growth } \\
\text { of teachers and principal. }\end{array}$ & Public & 2.60 & .997 & -11.176 & .000 \\
& Private & 3.69 & .665 & & \\
\hline
\end{tabular}

Significant $\alpha=0.05$

Table 8 shows that the value of " $t$ " $(-11.176)$ is significant as the " $p$ " value $(0.000)<0.05$ level of significant therefore it is concluded that there was a significant difference among public schools and private schools about the response that the rating system used to evaluate teachers is useful for the growth of principals and teachers.

Hypothesis 6: There is a significant difference among the public and private secondary schools in Karachi having indicators on the teachers' performance evaluation instrument includes all important aspects of teaching and learning.

Table 9

Teachers' Performance Evaluation Instrument Includes Indicators Related to all Important Aspects of Teaching and Learning $(N=300)$

\begin{tabular}{|c|c|c|c|c|c|}
\hline Response & Schools & Mean & $\begin{array}{l}\text { Standard } \\
\text { Deviation }\end{array}$ & $\begin{array}{l}t \text { - } \\
\text { value }\end{array}$ & $p$ \\
\hline \multirow{2}{*}{$\begin{array}{l}\text { Indicators on the teachers' performance } \\
\text { evaluation instrument includes all } \\
\text { important aspects of teaching and } \\
\text { learning. }\end{array}$} & Public & 2.37 & .902 & & .000 \\
\hline & Private & 3.04 & 1.003 & & \\
\hline
\end{tabular}

Significant $\alpha=0.05$ 
Table 9 indicates that the value of " $\mathrm{t}$ " $(-6.056)$ is significant as the "p" value $(0.000)<0.05$ therefore it is concluded that there was a significant difference among public schools and private schools about having all indicators in performance evaluation instrument related to all important aspects of teaching \& learning.

Hypothesis 7: There is a significant difference among the public and private secondary schools in Karachi regarding teacher's feeling of trustworthiness about the teacher's performance evaluation process.

Table 10

Teacher's Feel Trustworthiness about the Teacher's Performance Evaluation Process $(N=300)$

\begin{tabular}{llllll}
\hline Response & Schools & Mean & $\begin{array}{l}\text { Standard } \\
\text { Deviation }\end{array}$ & t-value & $p$ \\
\hline $\begin{array}{l}\text { Teacher's feel trustworthiness } \\
\text { about the teacher's performance } \\
\text { evaluation process }\end{array}$ & Public & 3.91 & .595 & .288 & .774 \\
& & & & & \\
\hline & Private & 3.89 & .608 & & \\
\hline
\end{tabular}

Significant $\alpha=0.05$

As highlighted in table 10 the value of " $t$ " $(0.288)$ is not significant as the "p" value $(0.774)>0.05$ therefore it is concluded that there was no significant difference among public schools and private schools regarding teachers' feeling of trust worthiness about the performance evaluation process.

Hypothesis 8: There is a significant difference among the public and private secondary schools in Karachi regarding regular informal visits by principal throughout the year.

Table 11

Regular Informal Visits by Principal throughout the Year $(N=300)$

\begin{tabular}{lllllll}
\hline Response & Schools & Mean & $\begin{array}{l}\text { Standard } \\
\text { Deviation }\end{array}$ & t-value & $p$ \\
\hline $\begin{array}{l}\text { Regular informal visits by } \\
\text { principal throughout the year. }\end{array}$ & Public & 2.51 & .988 & -15.099 & .000 \\
& & & & & \\
& & & & & \\
& & & & & \\
& & & & & \\
& & & & & & \\
\end{tabular}

Significant $\alpha=0.05$ 
As shown in table 11 the value of " $t$ " (-15.099) is significant as the "p" value $(0.000)<0.05$ therefore it is concluded that there was a significant difference among public schools and private schools about the regular informal visits by the principal throughout the year.

\section{Discussion}

Table 4 shows existence of a proper system of teachers' performance evaluation in all public and private schools as indicated by majority of the principals and teachers of these schools (mean 4.07 each) but this cannot be sufficient to ensure the quality of education because it is also important to find out that how frequently the performance evaluation was carried out to achieve its purpose. The performance of teachers in public schools is not monitored regularly (mean 2.23, SD 0.958) on the other hand the performance of teachers in private schools is monitored on regular basis (mean 4.10, SD 0.662). The irregular monitoring in public schools could be because the performance appraisal is required on annual basis only in public sector. A study by Iqbal (1997) supports our findings as he also revealed a better supervision and monitoring system in private sectors schools producing better results as compared to public schools. Literature also pointed out irregular monitoring and evaluation procedures of teachers' performance in the developing world due to lack of staff and lack of resources (Lewin \& Janet, 2003). A report by Grauwe (2004) mentioned about irregular inspections, with no quality control, leading to poor teacher performances in Africa.

Classroom observations is one of the major and direct indicator to evaluate teacher's performance as it demonstrates the teaching strategies, and student's learning at source. (Kane \& Staiger, 2012; Kane, Tyler, Tyler, \& Wooten, 2010; Milanowski, 2004; Santiago, Benavides, Danielson, Goe \& Nusche, 2013). The results in table 7 shows that private schools are better (mean 3.85, SD 0.560) as their principals were having adequate number of classroom observations to evaluate instructional skills of teachers as compared to public schools (mean 2.39, SD 0.843).

Linking professional growth opportunities to evaluation results is critical if evaluation is going to play a role in improving teaching and learning (Goe, Biggers and Croft, 2012). As shown in table 8, in majority of the public schools the rating system used to evaluate teachers was not useful for the growth of principals and teachers (mean 2.60, SD 0.997).In contrast, in majority of the private schools the rating system used to 
evaluate teachers was useful for the growth of principals and teachers (mean 3.69, SD 0.665).

The indicators on the teachers' performance evaluation instrument may be qualitative, or quantitative. A study by Parker (2002) revealed that developing countries follow mostly quantitative assessment indicators but except South Africa. Table 9 reflects that most of the public schools (mean 2.37, SD 0.902) did not have all indicators related to all important aspects of teaching and learning whereas most of the private schools (mean 3.04, SD 1.003) were having all indicators on the teachers' performance evaluation instrument related to all important aspects of teaching and learning.

The quality of teachers' performance evaluation process was also determined by its trustworthiness. As highlighted in table 10,most of the private schools as well as public schools were having a trustworthy performance evaluation process (mean 3.89, $S D 0.595$ \& mean 3.91, $S D$ 0.608 respectively). According to Bethell (2005) the fairness in performance evaluation process itself determines the perception of teachers about the impartiality of this process.

The formative nature of performance evaluation process in private schools was reflected by the statement that principals had regular informal visits throughout the year (mean 3.93, SD 0.592) as highlighted in table 11, whereas the summative nature of performance evaluation process in public schools was reflected through the statement that the principals did not have regular informal visits throughout the year (mean 2.51, SD 0.988) as the performance evaluation was carried out on annual basis. Grosin (2003) describes that school leaders in successful schools should visit classrooms to see the if teaching process is related to learning outcomes and discuss the process with their teachers to improve the quality of teaching.

\section{Conclusion}

The results of the study indicate that both public and private secondary schools in Karachi have a proper system of teachers' performance evaluation but a significant difference exists between teachers' performance evaluation systems of public and private secondary schools in Karachi in terms of quality. Our findings are supported by studies that also reveals that in private schools the performance evaluation system is more effective than public schools (Khan, Chandio, \& Farooqi, 2014; Farooqi, Khan, \& Arsalan, 2012). The results of the study are also in line with the results of a study by Tendon 
in India concluding performance evaluation that in private sector schools is more effective as compared to public sector.

The performance of teachers in public schools is not monitored regularly whereas the performance of teachers in private schools is monitored on regular basis.In private schools the principals were having adequate number of classroom observations to evaluate instructional skills of teachers as compared to public schools. In public schools the rating system used to evaluate teachers was not useful for the growth of principals and teachers unlike private schools where the rating system used to evaluate teachers was considered as useful for the growth of principals and teachers. The private schools were having all indicators on the teachers' performance evaluation instrument related to all important aspects of teaching and learning but public schools lack this quality.

The results concluded that both public and private secondary schools in Karachi have a trustworthy system of teachers' performance evaluation. The study also revealed that the quality of teachers' performance evaluation in private secondary schools is better than public secondary schools in Karachi. From the results of this study and other mentioned studies it is verified that in public sector schools that teacher's performance evaluation system is ineffective. The private sector schools are producing better results because of better system of performance evaluation and by applying effective and frequent evaluation system in public sector schools also, outstanding results can be produced. The private schools have a formative system of teachers' performance evaluation that is reflected through regular informal visits by their principal to check the performance of teachers. In contrast the public schools have a summative evaluation system to check the performance of teachers which was reflected through lack of regular visits by principal to check the performance of teachers.

\section{Recommendations}

It is expected that the principals of the schools should play the role of a mentor and brief their teacher about the indicators of teacher's performance evaluation instrument so that the teachers can perform well according to the set standards when they were observed. It is important that the teachers need to have a complete understanding about the indicators of teacher's performance evaluation instrument to perform accordingly and to know that these indicators would be the basis of their judgment. The teachers will also trust the judgment of their performance if they know the indicators of performance instrument. 


\section{References}

Abbas, S. (1993). The power of English in Pakistan. World Englishes, 12 (2), 147-156.

Aguinis, H. (2009). Performance management ( $2^{\text {nd }}$ ed.). Upper Saddle River, NJ: Pearson Prentice Hall.

Bethell, R. (2005). School evaluation, teacher appraisal and feedback and the impact on schools and teachers: Creating effective teaching and learning environments. First results from TALIS. Retrieved from www.oecd-ilibrary.org.

Cokins, G. (2004). Performance management: Finding the missing pieces and closing the intelligence gap. Australia: John Wiley and Sons.

Cubberly, E. P. (1929). Public school administration: A statement of the fundamental principles underlying the organization and administration of public education. Boston, MA: Houghton Mifflin.

Danielson, C. (2001). New trends in teacher evaluations. Educational Leadership, 58(5), 12-15.

Danielson, C., \& McGreal, T.L. (2000). Teacher evaluation to enhance professional practice. Alexandria, VA: Association for Supervision and Curriculum Development (ASCD) Publishers.

Erdogen, B. (2002). Antecedents and consequences of justice perceptions in performance appraisal. Human Resource Management Review, 12, $555-578$.

Farooqi, M.T.K., Khan, H.M.A., \& Arsalan, M. (2012). Comparison of performance appraisal system in public and private sectors higher secondary schools. The Sindh University Journal of Education,41, 148-166.

Gay, L. R. (2013). Educational research: Competencies for analysis \& application, $\left(6^{\text {th }}\right.$ ed.) New Jersey: Merrill/Prentice Hall.

Goe, L., Biggers, K., \&Croft, A. (2012). Linking teacher evaluation to professional development: focusing on improving teaching and learning. Washington, DC: National Comprehensive Center for Teacher Quality. 
Government of Pakistan. (2009). National Professional Standards for Teachers in Pakistan. Islamabad: Policy and Planning Wing, Ministry of Education.

Grauwe, A. D. (2004). Decentralization and school improvement: A Comment on research in West-Africa. Washington: International Institute for Educational Planning. International Working Group on Education.

Grosin, L. (2003). Research on successful schools as the basis of school development, in Swedish. In Berg \& Scherp (Eds.), The many faces of school development, in Swedish. Stockholm: Myndigheten för skolutveckling, Liber.

Iqbal, M. (1997). Public versus Private secondary schools: A qualitative comparison. Journal of Research and Reflections in Education, 6(1), $40-49$.

Kane, T.J., Taylor, E.S., Tyler, J.H., \&Wooten, A.L. (2010). Identifying effective classroom practices using student achievement data. Cambridge, Massachusetts: National Bureau of Economic Research.

Kane, T.J., \& Staiger, D.O. (2012). Gathering feedback for teaching: Combining high-quality observations with student surveys and achievement gains. MET Project Policy and Practice. Washington: Brief, Bill and Melinda Gates Foundation, Seattle.

Khan, H.M.A., Chandio, J.H., \& Farooqi, M.T.K. (2014). Comparison of performance appraisal system in public and private schools. Pakistan Journal of Commerce and Social Sciences, 8 (1), 272-278.

Lam, S. (2001). Educators' opinions on classroom observation as a practice of staff development and appraisal. Teaching and Teacher Education, 17, 1-14.

Lewin, K. M., \&Janet S. (2003). Researching Teacher Education: New Perspectives on Practice, Performance and Policy. Multi-Site Teacher Education Research. UK: Centre for International Education, University of Sussex Institute of Education.

Mani, B. (2002). Performance appraisal systems. Productivity and motivation. A Case study. Public Personnel Management, 32 (1), 141-159. 
Milanowski, A. (2004). The relationship between teacher performance evaluation scores and student achievement: Evidence from cincinnati. Peabody Journal of Education,79(4), 33-53.

Parker, B. (2002). Roles and responsibilities, institutional landscapes and curriculum. Mindscapes: A partial view of teacher education policy in South Africa, 1990-2000. Multi-Site Teacher Education Research Project. Discussion Paper 30. University of Sussex, Institute of Education.

Payos, R. P., \& Zorilla, O. S. (2003). Personnel management in the 21st century (7th ed.). Manila, Philippines: Rex.

Rahman, S. A. (2006). Attitudes of Malaysian teaches towards a performance appraisal system. Journal of Applied Social Psychology, 36(12), 3031-3042.

Rahman, T. (2002). Government policies and the politics of the teaching of Urdu in Pakistan. Annual of Urdu studies, 17,95- 124.

Robbins, P., \& Alvy, H.B. (2003). The principal's companion: Strategies and hints to make the job easier. Thousand Oaks, CA: Corwin.

Roberts, G. (2003). Employee performance appraisal system participation. A Technique that Works. Public Personnel Management,32 (1), 89-98.

Santiago, P., Benavides, F., Danielson, C., Goe, L. \& Nusche, D. (2013). OECD Reviews of Evaluation and Assessment in Education: Teacher Evaluation in Chile. Paris: OECD Publishing, Paris. Retrieved from http://dx.doi.org/10.1787/9789264172616-en

Sarwar, S., \& Awan, U. (2013). Performance evaluation in private schools: A case study of the educators school. Journal of Public Administration and Governance, 3(4). 82-99.

Shakir, M., \& Adeeb, M.A. (2014). Performance appraisal: An evaluation of teachers' competencies based on national professional standards in Pakistan. International Review of Social sciences, 2(12), 532-543.

Strong, J., \& Tucker, P. (1999). The politics of teacher evaluation: A case study of new system design and implementation. Journal of Personnel Evaluation in Education, 13(4), 339-359. 
Stronge, J. H., \& Tucker, P. D. (2003). Handbook on teacher evaluation: Assessing and improving performance. Larchmont, NY: Eye on Education.

Stronge, J.H. (2010). O que funciona, de facto, na avaliação de professores: breves considerações. In M.A. Flores (ed.) A Avaliação de Professores numa Perspectiva Internacional: Sentidos $e$ Implicações. Porto: Areal Editores.

Vanci-Osam, U., \& Aksit, T. (2000). Do intentions and perceptions always meet? A case study regarding the use of a teacher appraisal scheme in an English language teaching environment. Teaching and Teacher Education, 16, 1-15.

Wilson, J. P. (2005). Human Resource Development ( $2^{\text {nd }}$ ed.). London: Kogan.

Zimmerman, S., \& Deckert-Pelton, M. (2003). Evaluating the evaluators: Teachers' perceptions of the principal's role in professional evaluation. NASSP Bulletin, 87(636), 28-37.

\section{Citation of this Article:}

Hyun, R. J., \& Sajjad, S. (2018). Quality of teachers' performance evaluation in public and private secondary schools of Karachi, Pakistan.

Pakistan Journal of Education, 35(2), 157-174.

Received on: February 22, 2018

Revised on: July 05, 2018

Accepted on: July $\quad 18,2018$ 